\title{
Development, Displacement and Resettlement a Challenge for Social Sustainability: A Study on Mega Development Project (Bakun Dam) In Sarawak
}

\author{
Reazul Ahsan ${ }^{1}$, and Mohd Hamdan Bin Haji Ahmad²
}

\begin{abstract}
Any mega development projects like urban renewal or infrastructural development projects, such as dams and highways require land and often in large quantity. The most common consequences of all mega projects are upheaval and displacement of the local residents and communities. Displacement due to physical development encompasses more than the loss of land: displaced communities also lose their social structure, energy over lives and loss the traditional process of living and economic resources. Resettling such displaced communities become a challenge for social sustainability. Bakun hydroelectric dam under the Sarawak Corridor of Renewable Energy (SCORE) is an example of such displacement and resettlement program under mega development projects in East Malaysia. Such mega projects resettled almost 10,000 people from the 70,000-hectare land where they have been living for generations. Such development-induced displacement become a sustained challenge for Sarwak areas in terms of social justice, economy, and environment. This study, conducted in the Bakun dam area aims to understand the challenges faced by resettled communities in Sarawak. This study used Cernea's Impoverishment Risks and Reconstruction (IRR) model for advocating better alternative for ensuring social sustainability of such resettlement project.
\end{abstract}

Keywords - urban sustainability, development, displacement and resettlement.

\section{INTRODUCTION}

A NY mega development projects like urban renewal or infrastructural development projects require land and often in large quantity. The most common consequences of all mega projects are upheaval and displacement of the local residents and communities. Displacement due to physical development encompasses more than the loss of land: displaced communities lose their social structure, energy over lives and loss the traditional process of living and economic resources. Resettling such displaced communities become a global challenge and also become a part of the sustainable development challenge [1]. Development-induced displacement and resettlement (DIDR) has stayed in one of the most contentious topics in innovative urban and economic evolution, particularly for Asian nations where the economy is

\footnotetext{
${ }^{1}$ Research Fellow, MIT-UTM Sustainable Malaysian City Program, Universiti Teknologi Malaysia

${ }^{2}$ Professor, Institute of Sultan Iskandar, Universiti Teknologi Malaysia.
}

demanding a turn from subsistence farming in the high industrial economy. In any mega scale development project costs and benefit analysis is more important than the study of social implication of displacement. Development induced displacement is hardly a new social, sustainability issues, especially for the urban development process. The number of affected people has grown dramatically mostly in developing nations like Malaysia, India and China, where rapid physical infrastructure development is considered as a solution of economic growth and sustainability [2].

Malaysia is one of the most ambitious examples in Southeast Asia by investing millions in collaboration with foreign investors to meet the growing housing and economic demand. The new development goal of Malaysia is to be a high income and sustainable developed nation by 2020 under 1Malaysia plan [3].

Enough provision of energy, especially electrical energy is the greatest challenge for Malaysia to sustaining its industrial development momentum. It also indicates that per capita energy consumption need to grow to meet up the future development challenges. The growth of per capita energy consumption has come to be associated with the construction of mega dams considered as a mega infrastructure development [4]. The State government and the state-owned energy company Sarawak Energy Berhad (SEB) to build a series of up to twelve large-scale dams to generate hydroelectric power. The aim of such large scale project is to expand the industrial economy in the Sarawak region under the industrial development initiative called the Sarawak Corridor of Renewable Energy (SCORE). Among all those hydroelectric dams, Bakun dam is considered as one of the largest dams in the world and is the largest in Southeast Asia. The dam is $205 \mathrm{~m}$ high with an installed capacity of 2400 megawatts (MW), and a lifespan of 50 years. The impoundment of the dam will inundate 69,640 ha of forest ecosystem - an area larger than the size of Singapore. The project is estimated to cost RM9 billion and displace more than 10,000 indigenous people from their land [5].

This article is a qualitative research approach to understand the impoverishment and the alternative process necessary for ensuring better livelihoods of the displaced community due to mega development projects such as Bakun Dam. This research aimed to use Impoverishment Risks and Reconstruction (IRR) 
model introduced by Michael M. Cornea in 1990's.

\section{A. Impoverishment Risks and Reconstruction (IRR) model:}

Impoverishment Risks and Reconstruction (IRR) model was first designed by Cernea in 1990 and has been considerably changed since then to accommodate new development issues. However, the core of the IRR model are three basic concepts: risk, impoverishment and reconstruction. The model is aimed" (a) to explain what happens during massive displacement due to development and (b) to create a theoretical and safeguarding tool capable of guiding policy, planning and actual development programs to counteract these adverse effects" [6]. This article is addressing the development-induced displacement challenges in modernizing countries like Malaysia, where forced resettlement carries several risks of impoverishing the uprooted people, many of whom are really poor even before displacement. According to Cernea [7] the IRR model addresses impoverishment not only from "incomepoverty" perspective, but the model also considers other social challenges such as losing employment opportunities, housing, health, education and community power or social status. According to the IRR model the most general risks that are linked to developmental displacement are:

\begin{tabular}{l|l} 
01.Landlessness & 02.Joblessness \\
\hline 03.Homelessness & 04.Marginalization \\
\hline $\begin{array}{c}\text { 05.Increase morbidity and } \\
\text { mortality }\end{array}$ & 06.Food insecurity \\
\hline $\begin{array}{c}\text { 07.Loss of Access to common } \\
\text { property }\end{array}$ & $\begin{array}{c}\text { 08.Social disarticulation } \\
\text { (community) }\end{array}$
\end{tabular}

This research using this model and the general risks addresses in this model to understand the challenges of social sustainability faced by the displaced communities by the Bakun dam in Sarawak.

\section{BAKUN DAM, DISPLACEMENT AND RESETTLEMENT OF INDIGENOUS PEOPLE}

According to the International Commission on Large Dams (ICOLD), a dam is considered as "large dam" has to be minimum $15 \mathrm{~m}$ tall or must carry at least 3 million cubic meters of water [8]. Based on ICOLD Bakun meets all the criteria of a large dam, located at Balui river about $200 \mathrm{~km}$ from Bintulu town in Sarawak. Bakun dam is designed to generate $2,400 \mathrm{MW}$ of electricity. Initially, it was planned that almost $70 \%$ of generated electricity would deliver to Peninsular Malaysia and rest will use for East Malaysia. Later it was decided that Bakun;s power will remain in Sarawak to develop this region a new economic hub under the SCORE project by 2020 [9]. Following table 1, presents the summary of the Bakun dam [10]:
TABLE I

SUMMARY OF BAKUN DAM

\begin{tabular}{ll}
\hline \hline Issue & Facts/Impacts \\
\hline Project cost & RM 15 billion \\
Self-life & 50 years \\
Type of the dam & Concrete Face Rockfill Dam (Highest in the world) \\
Land inundated & 69,640 hectares \\
Catchment area & 1.5 million hectares \\
Capacity & Generator of 2,400 MW electricity \\
Site & Balui river 37 km upstream from Belaga Power \\
Transmission & $\begin{array}{l}1,500 \text { km overland wires, 650 submarine cables } \\
\text { Turnkey contract }\end{array}$ \\
Ekran Bhd \\
Social impact
\end{tabular}

Besides all economic benefits large dams also have some geological and social impacts which are clearly addressed in the book "Silenced rivers: the ecology and politics of large dams". In that book it is clearly addressed that large dams always cause displacement and in most cases the indigenous people are the victims who are well known as "son of the land". It is estimated that only in China more than 30-60 million people displaced due to river dam projects [11]. The Bakun dam has the same character, almost 10,000 indigenous people are displaced due to this mega project. Moreover, such displacement and resettlement often cause hardship for the indigenous people, many of them failed to secure a job in their new location or they unable to continue their agricultural or hunting activities prior to their resettlement [12].

\section{A. Indigenous people or Orang Asli}

Orang Asli (Orang means People and Asli means original) or indigenous people who are the holders of their own unique language, culture, beliefs and knowledge of living with the environment for the sustainable management of natural resources. They are the people who are connected and linked to the land. Their inherited land has a significant value for their physical and cultural survival as peoples [13].

Orang Asli in Malaysia are classified into 95 subgroups with their own distinct language and acculturation. Nonetheless, they are all marginalised socioeconomic and culturally in Malaysia. However, the natives of Sabah and Sarawak are in a relatively vulnerable position due to heavy construction projects like dams [14]. About 15 different communities in East Malaysia, namely Kenya, Kayan, Kajang, Ukit and Penan consist almost 10,000 relocated due to the dam. The greater number of them were subsistence farmers and were getting their protein needs from fishing and hunting. For this project about 170,000 acres of jungle is cleared, which was the home of more than 100 species of fauna, include the great leaf monkey, Borneon Gibbon and Malayan Sunbear [9].

Those different communities of Orang Asli people lived in Bakun are well addressed or classified by their location or "Home of Stay". For example, one group is known as Orang Ulu (People of the upstream) they used to live along the upstream river and another group is known as Orang Penan (People of the forest) they lived in the forest areas. Both the Orang Ulu and Orang Penan people are displaced due to 
Bakun dam and now resettled in Belega district, Sarawak. In their new settlement they are also known by their long-house known as Rumah Panjang. Such identity clearly indicates the character and connection with the land they live and belong.

\section{B. Rumah Panjang (Long-houses)}

Those Orang Ulu and Orang Penan people are resettled in 15 Rumah Panjangs (long houses) in one village, and the village called Sungai Asap, in Belega district. This study has been conducted with the people in Sungai Asap living in those long-houses. According to the field survey all together 10,000 residents currently living in all those 15 long-houses. Each of this long-house is known by a name and the residents are also identified based on their long houses. Following figure (Fig. 1) shows the google satellite image of the long-houses in Sungai Asap.

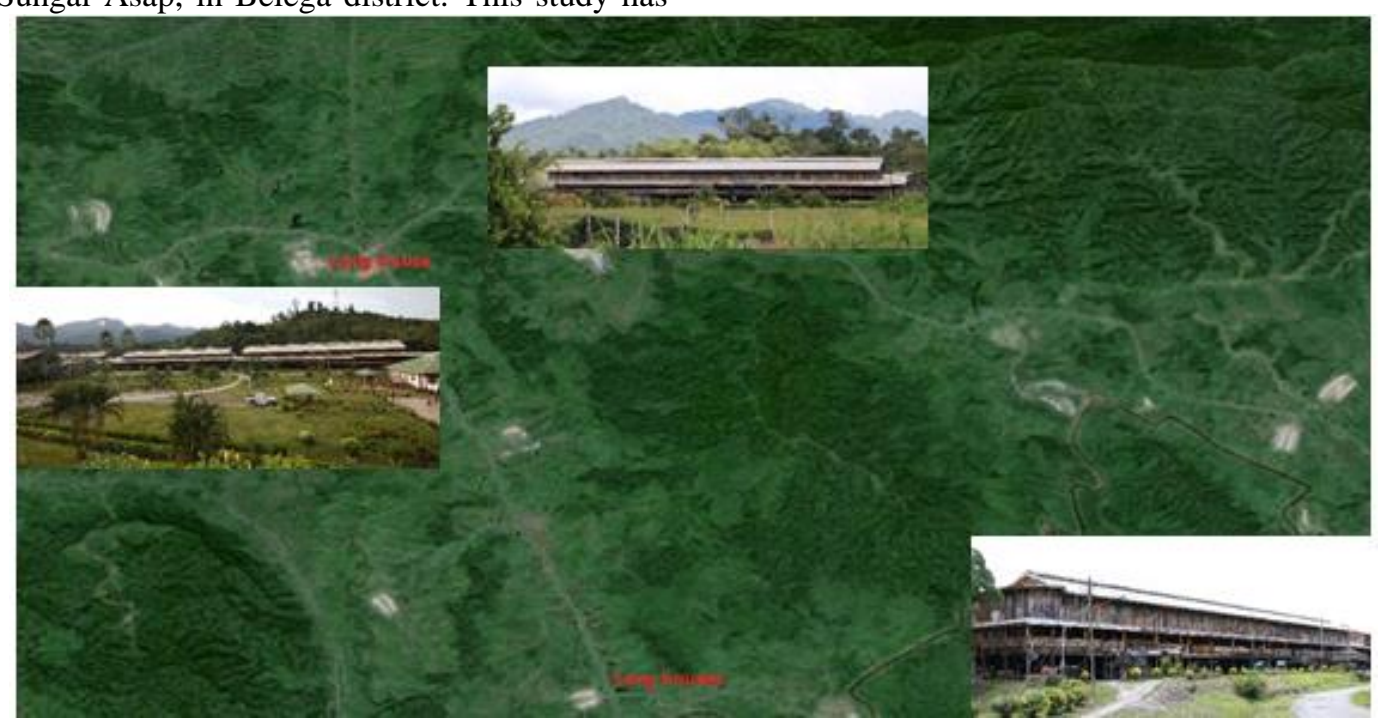

Fig. 1: Location Rumah Panjang/long-houses in Sungai Asap

Those 15 long-houses are named as Lebu Kulit, Uma Belor, Uma Daro Uma Nyaving, Uma Kelap, Uma Lahanar, Uma Bawang, Uma Balui Lito, Uma Balui Ukap, Uma Bakah, Uma Badong, Uma Penan Talun, Uma Juman, Uma Le song and Uma Ukit. According to their cultural norms, these longhouses are administrated by local leaders who are selected among them and appointed by the local government to protect their culture, ethics and social structure and value. Figure 2 explains is the administrative hierarchy of the Sungai Asap village to marinating the long-houses:

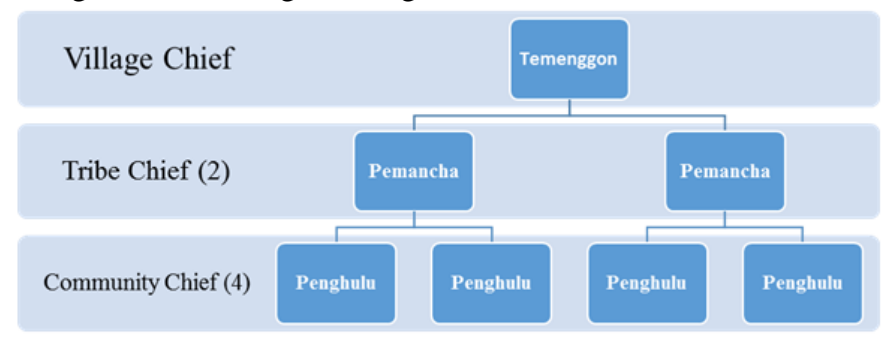

Fig. 2: Administrative hierarchy of Sungai Asap

Beside the existing government law of Malaysia, local police station as a law enforcement agency and a government administrative authority (district council), those Orange Ulu and Orange Penan people still practice their own administrative system, because of their ethnicity and culture. This administrative system was used by the government to convince the indigenous community to relocate them from the Bakun areas.

\section{BAKUN DAM-INDUCED DISPLACEMENT AND RELOCATION CHALLENGES}

According to one of the Penghulus, Mr. Ebao, and Pemanachas Mr. Umengeno, at the first phase of relocation process the residents were informed that they are going to relocate from the Bakun areas due to the new hydroelectric power projects. However, they were not aware of the relocation plan, the level of compensation and facilities they may have in their new location. Local residents formed Bakun Relocation Committee (BRC) to negotiate with the government authority and Mr. Ebao and Mr. Umengeno were on that committee. They also addressed that the relocation process may be addressed as a democratic process, but most of their elderly were not agreed to be relocated to a new place because of their subsistence farming and their attachment to land and water. Moreover, they were not confirmed how much land they will have at a new location and what would be their way of living and earning. Orang Asli people are very much connected with forest and river for their food and living, Bakun was a perfect place for them to get their food and living because of the river Balui and adjacent forests. From that perspective at the very first phase, they consider it to be displacement rather relocation or resettlement.

This study is aimed to assess the general risks (section 1.1) of those displaced people, to answer whether the resettlement plan is a challenge for social sustainability or not, by using the IRR model. As it is stated that this is a qualitative research, therefore the local community was asked what are the major challenges they faced of being relocated during the focus group discussion. Almost $90 \%$ of the total respondents (41 
respondents out of 45) addresses that the land they are having after reallocation is not enough for their sustenance. As a part of the relocation plan, each house in Bakun has allocated 3.1 hectares of land (7 acres) when some of them had more than 100 hectares of land and they had complete freedom to cultivate wherever they want. To compare their old property this 3.1 ha of land is not enough for a family of 3 and they are kind of forced to find an alternative income source. The land parcel they are having now for farming is surrounded by palm plantation area and also marked by the government agriculture and land department. Therefore, there is no more common access to land as before to cultivate as much land as they can.

Landlessness considering the IRR model, where landlessness is a key challenge for displaced and relocated communities, these indigenous communities are not completely landless, but the land they are having is not enough to support their living. Most of the residents are now involved in different other economic activities to support their family. Another key challenge that forced them to involve in different economic activities is their family expenditure. Based on the interview with another Penghulu Mr. Lebu Kulit and a community member Li-Wong, in this new settlement they have to pay for everything, water supply, electricity, and infrastructures. They are not used to pay a tariff as they don't have these facilities before. They do agree that those facilities improve their quality of life, but the land is not enough to earn to meet all those expenditures.

Marginalization based on field observation and focus group discussion that indigenous community is no more jobless or homeless. However, the elderlies are marginalized in the society as they can't cope with modern technologies like mobile phones and car. They are habituated to row boats along the river, fishing, and farming and socialization. A very good example is Deng Ngo, 85 years old widow and still having the mark of her own tribe in her hands.

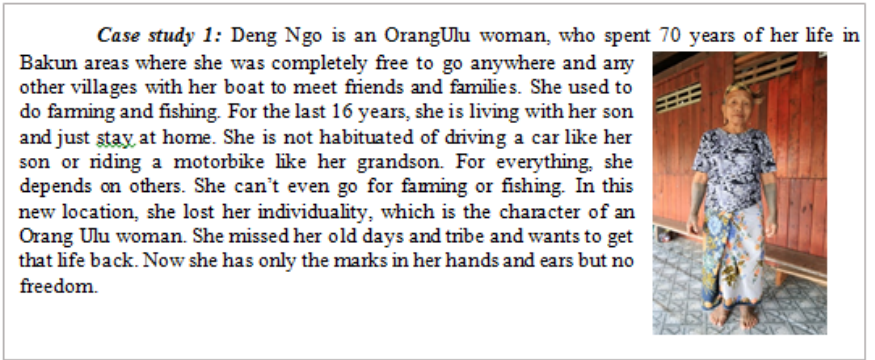

The new village Sg. Asap now they have a clinic for better health service and modern hospital facilities are in Bitulu city, which is just $153 \mathrm{~km}$ away from them. Morbidity and mortality are no more a challenge for those communities as it was before in Bakun area. During those days in Bakun, it took them 3 days to go to the hospital, as addressed by Penghulu and Pemanacha. Now they also have 2 primary and a secondary school to ensure quality education for the young generation to fit for modern Malaysia. However, the challenges are not yet over, they still have food insecurity and limited access to common properties. Food insecurities for them means a shortage or unavailability of food. As the land they have now in their new settlement is not enough. At the same time in their new place they do not have access to the forest and rivers where they get foods and that scarcity of food lets them go back to the Bakun dam area where they have access to the common property for fishing and hunting. A 50 years old lady Aijun $\mathrm{Ng}$, who also gets a room in Rumah Panjang in Sg. ASAP, but moved back to her old place along the Bakun dam so she has easy access to food.

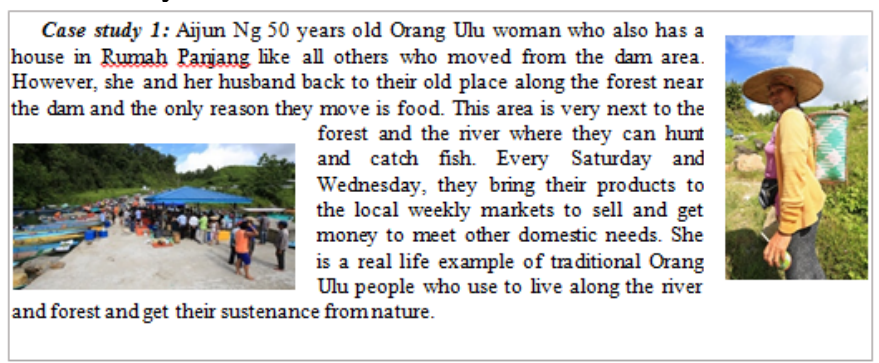

Compare to any other relocation or displacement process due to development projects the Orang Ulu and Orang Penan people are well off as per IRR model. Because the relocation process was much more democratic and they receive better alternative and modern facilities like, school, clinic, water supply and electricity in their new settlement area. Yes, there are challenges and risks involved with their relocation process, as per IRR model, which is addressed above. However, the local community is working hard to overcome all those challenges, as it has been 17 years since they moved from their original place. The young generation is now having opportunities to go to school and have higher education facilities. Within the last 17 years, almost 170 people from their community got their university Diploma and now working in all over Malaysia. They choose a modern lifestyle rather following the footprint of their ancestors. Moving towards urban life style may introduce social disarticulation and may lose their heritage and culture. The community together and along with the community leaders are working on this social risks. As per community initiatives each room in every long-house is named after that family and they are known by that long-house to be connected with their tradition. Furthermore, young people are encouraged to come back to their village in every Christmas so they feel and continue the family and social bondage to their tribe.

\section{RESETTLEMENT, SOCIAL CHALLENGES AND SUSTAINABILITY}

Resettlement programmes have predominantly focused on the cognitive operation of physical relocation rather than economic, societal and emotional development of the displaced masses. Displaced or relocated communities usually face different challenges at different stages of the relocation process to sustain in a new location and that is the challenge of social sustainability of wrestlers [15]. The Orang Ulu and Orang Penan people in the Bakun area also passed those days and yet they are struggling to be settled and to have a sustainable life in their new settlement. Figure 3 presents the challenges faced by those communities based on focus group discussion results. 


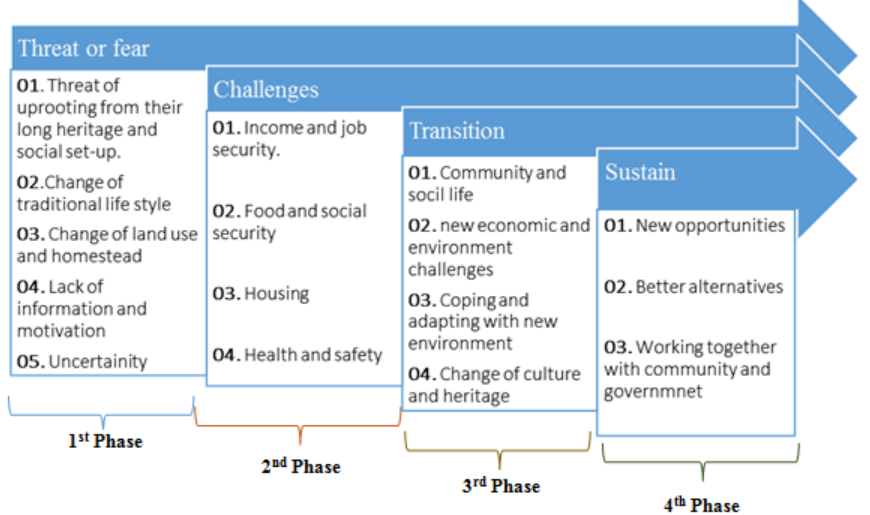

Fig. 3: Challenges at different stages to achieve social sustainability in the resettlement process

The indigenous communities in Bakun pass all those challenges of resettlement process and now working to sustain and to ensure a quality life in their new place. According to the field survey, at the early stage of the relocation process, they were confused and afraid to be relocated. They had very limited information and not much choice but to move. After being relocated they had to struggle a lot to make the new place a home. There was not much land to cultivate, not many jobs to earn their livings. Over the time with the support of local government, they had to work hard to build their community, face the economic and environmental challenges and find a better adaptation approach to make this place new home. Now they are struggling to be sustainable and the challenges they have is to find new opportunities for them and for the new generation to stay in Rumah Panjang, new alternatives such as local tourism to generate income, better option to work together with the community and the government to uphold their culture and heritage.

Compared to many other displaced and resettlement examples, resettlement process in Bakun is a success story. Based on community survey, it is clear that their life standard is now much better than before. They are having better health, education, water supply and sanitation facilities. They are also having community halls and stadiums for social gathering. It takes almost 17 years to be at this stage since they are relocated, however, with all those challenges they are still working to find a better alternatives and opportunities to be economically and socially sustainable, where they have more opportunities to earn and to uphold their culture and heritage.

\section{REFERENCES}

[1] A. Oliver-Smith, "Introduction: Development-Forced Displacement and Resettlement: A Global Human Crisis", in Development \& dispossession: the crisis of forced displacement and resettlement, Ed A. Oliver- Smith, Cambridge University press, 2009, ch. 1, pp. 3-24.

[2] Neef and J. Singer, "Development-induced displacemnet in Asia: conflicts, risks and resilience", Development in Practice". vol. 25, pp. 601-611, 2015.

http://dx.doi.org/10.1080/09614524.2015.1052374

[3] S.Sintusingha (....2015). Two side of the same coin? Neolibera, Social and Class in Southeast Asia, The Rise and Fall of Social Housing: Future Direction, [online], 1(1), pp.1-8. Availabale: http://www.fusionjournal.com/issue/006-fusion-the-rise-and-fall-of-social-housing-futuredirections.
[4] C. Y. Keong, "Energy demand, economic growth, and energy efficiency - the Bakun dam-induced sustainable energy policy revisited," Energy Policy, vol. 33, pp. 37-45. 2005. http://dx.doi.org/10.1016/j.enpol.2004.10.001

[5] T. Lee, T. Jalong and W. Meng-Chou (September 2014). No consent to proceed: Indigenous Peoples' Rights Violations at The Proposed Baram Dam in Sarawak. Save Sarawak Rivers Network (SAVE Rivers). [online]. http://www.forestpeoples.org/sites/fpp/files/publication/2014.

[6] M. M. Cernea, "For a new economics of resettlement: a sociological critique of the compensation principle," International Social Science Journal, vol.55, pp.37-45, June 2004a. http://dx.doi.org/10.1111/1468-2451.5501004

[7] M. M. Cerne, "Impoverishment Risks, Risk Management, and Reconstruction: A Model of Population Displacement and Resettlement”, in Proc. 2004 UN Symposium on Hydropower and Sustainabale Development., 2004, pp 13-52.

[8] N. Schauner (October 2014). World's Highest dams, International commission on Large Dams, [online], Available: http://www.icoldcigb.org/GB/World_register/general_synthesis.asp?IDA=207.

[9] S. A. Ariffin (2013). Environmnetal Justice Study: Displacement of Indigenous People in Sarawak, Malaysia. Malaysian, Friends of Earth. [online]. Availabale: http://umich.edu/ snre492/Jones/malaysia.htm.

[10] S. M. M. Idris (November 2015). A brief of Bakun Dam. Sahabat Alam Malaysia. [online]. Available: www.surforever.com/sam/sarawak/articles/bakunbrief.html.

[11] P. McCully, Silenced Rivers: The Ecology and Politics of Large Dams, 1st ed, London, U.K, Zed books. Ltd, 2001, ch. 1, pp.1-25.

[12] S. Then (October 2009). No jobs for Bakun men, The Star, [Newspaper], 29 October, pp.4.

[13] N (United Nations) (September 2008). United Natios declaration on the right of indigenous people, United Nationa, [online], pp. 1-15. Available: http://www.un.org/esa/socdev/unpfii/documents/DRIPS_en.pdf.

[14] T. Masron, F. Masami and N. Ismail, "Orang Asli in Peninsular Malaysia: Population, Spatial Distribution and Socio-Economic Condition", Journal of Ritsumeikan Social Sciences and Humanities, vol. 6, pp. 74-115. 2012.

[15] WCD (World Commission nf Dams) (November 2000). Displacement, Resettlement, Rehabilitation, Reparation, and Development, World Commission on Dams, [online]. pp. 1-15. Availabale: http://siteresources.worldbank.org 